\title{
Abiotic Factors Influencing Tropical Dry Forests Regeneration
}

\author{
Eliane Ceccon $^{1 *}$, Pilar Huante ${ }^{2}$ and Emanuel Rincón ${ }^{2}$ \\ ${ }^{l}$ Centro Regional de Investigaciones Multidisciplinarias; Universidad Nacional Autónoma de México; Av. \\ Universidad, s/n; Circuito 2; Colonia Chamilpa; ececcon@miranda.ecologia.unam.mx; Morelos 62210; \\ Cuernavaca - México. ${ }^{2}$ Instituto de Ecología; Universidad Nacional Autónoma de México; AP 70-275; D. F. 04510; \\ México
}

\begin{abstract}
Tropical dry forests represent nearly half the tropical forests in the world and are the ecosystems registering the greatest deterioration from the anthropogenic exploitation of the land. This paper presents a review on the dynamics of tropical dry forests regeneration and the main abiotic factors influencing this regeneration, such as seasonal nature, soil fertility and humidity, and natural and anthropic disturbances. The main purpose is to clearly understand an important part of TDF succession dynamics.
\end{abstract}

Key words: Tropical dry forests, regeneration, disturbances, seasonal variability, fertility, moisture

\section{INTRODUCTION}

Tropical dry forests (TDF) represent more than $40 \%$ of tropical forests in the world covering large areas in Africa, Australia, Central and South America, India and South-East Asia (Murphy and Lugo 1986). In many regions of the planet, TDF are subject to human disturbances which are more persistent and extensive than those appearing in tropical humid forests (Murphy and Lugo, 1986; Janzen, 1988). Unlike tropical humid forests, TDF occur on climates with highly seasonal rainfall. Gerhardt and Hytteborn (1992) established the climatic limits of these forests in areas in which the dry period lasted about six months, of one or two seasons, with annual rainfalls between 400 and $1700 \mathrm{~mm}$. The highly seasonal rainfall pattern of TDF generates abiotic conditions that are more severe and variable than in tropical rain forests. Thus, tropical dry forests tolerate conditions of greater stress during the succession process. In this respect, the heterogeneity of the spatial and temporal availability of resources largely control the phenological patterns (Bullock and SolisMagallanes, 1990; Medina and Cuevas, 1990), the production of seeds (Ray and Brown 1994), germination (Miller, 1999), survival, and the establishment of seedlings (Lieberman and $\mathrm{Li}$ 1992; Swaine 1992; Gerhardt 1998). In this heterogeneous environment, germination must occur in a limited period of time so that seedlings have favorable light, nutrient and water conditions to settle. Some of these aspects have already been examined by Rincón et al. (1999); Khurana and Singh (2001), but the revision of aspects related to factors influencing the differentiation of species during the TDF succession process is not complete. Specifically, the study of the abiotic factors that poses influence on the regeneration of seedlings is essential for understanding the TDF

* Author for correspondence 
dynamics and, by the other hand, for addressing key issues on restoration and conservation of these ecosystems.

We analyze in this paper some ideas that have been advanced to explain the regeneration process in TDF, in order to understand some aspects of their successional dynamics.

\section{TROPICAL DRY FORESTS REGENERATION}

\section{Ecology of seeds}

The dispersion of seeds in TDF occurs mainly during the dry season (Bullock and Solis Magallanes, 1990); seeds remain on the forest floor until the next rainfall season when they encounter more favorable conditions for germination and growth. Studies carried out in the TDF of the Virgin Islands, in the Caribbean Sea, and Guanacaste (Costa Rica) show that the percentage of woody species dispersed by wind is lower than that dispersed by animals. Wind dispersal in these regions occurs on the dry season, while animal dispersion occurs during the rain season (Janzen 1988: Ray and Brown 1994). However, it has been found that natural regeneration in an abandoned pasture of 12 yearsold, with a mature forest $200 \mathrm{~m}$ away, was mainly the consequence of species dispersed by the wind, because animals rarely adventure to visit pastures with little or no remanent stands (Janzen, 1988). Also in various TDF in Nicaragua, Sabogal (1992) found that seeds belonging to species dispersed by the wind prevail in the mature forest and in early sucessional stages. This author relates this phenomenon to other disturbances occurring in the region that cause the local disappearing of most of the vertebrates, and to the high resistance to drying present in open sites by the wind dispersed species.

Most seeds in TDF have the capacity to rapidly germinate from the moment they reach the forest land. This is considered an evolutionary response to favorable conditions (high percentage of humidity on the upper soil layer) that may be present for only very short periods (Skolung, 1992; Miller, 1999). This fast germination is only sucessful if it also means predation avoidance associated to an abundant fructification (Hopkins and Grahan, 1983; Uhl and Clarck, 1983; Bullock and Solis-Magallanes, 1990).
Regarding the effects of storage time on TDF seed germination, most of the species analyzed by Ray and Brown (1994) lost their germination capacity in the first 10 months of storage in dryness and cold conditions. The survival of seeds in nature is normally shorter than those in laboratory conditions, since in the latter some factors such as predation and pathogen attacks are less frequent and the micro environmental conditions are more stable (Garwood, 1989). Leguminous trees were shown to have long-lived seeds in a study by Ray and Brown (1994) because these species have seeds with an impermeable tegument. However, very few seeds of this family were found in the soil.

Seed bank has a reduced role in the regeneration of TDF because very few species have been found to have seeds with a high percentage of germination, after remaining in the seed bank for a long time (Skoglund, 1992; Rico-Gray and Garcia-Franco, 1992; Miller, 1999). Ray and Brown (1994) examined 29 TDF species in a greenhouse and in more than a half (17) latency was absent. On the other hand, in other studies a highly marked latency has been found among species fructifying only during the dry seasons (Foster, 1982; Garwood, 1982). Therefore, latency in TDF may form a short-lived seed bank, present during the dry season until the arroival of the rainfall season.

Garwood (1989) suggest that the TDF seed banks contain much fewer seeds $\left(55-696 / \mathrm{m}^{2}\right)$ than the rain forests $\left(60-4700 / \mathrm{m}^{2}\right)$. Rico-Gray and GarciaFranco (1992) found 70 to 855 seeds $/ \mathrm{m}^{2}$ in disturbed sites abandoned for 10 to 100 years in Yucatán, Mexico. These authors found only one tree species (Lysiloma latisiliqum), whereas herbaceous seeds were plentiful. In another study in Mexico (Chamela) Miller (1999) also found a very low amount of tree seeds in the TDF seed bank, immediately after the fructification period. Among the major factors that might explain the low amount of seeds found in the TDF seed banks are the high seed mortality rates due to environmental stress or predation, restrictions in the dispersal and germination process of seeds in favorable periods, followed by a low recruitment of seedlings in dry periods (Ray and Brown 1994). Campbell et al. (1990), in a study of TDF of different ages, from two years-old up to a climax forest in Mozambique, summarized the importance of seed rain and the seed bank for these ecosystems and reported that it was the seed rain and not the seed bank what directed succession in the TDF. 


\section{Sprouting as a regeneration mechanism}

Based on the structure and composition of the TDF trees communities present along the succession process, various authors have showed that most tree species regenerate by sprouting (Ewel 1977; Kauffman 1991; Murphy and Lugo, 1986; Rico-Gray and Garcia-Franco, 1992; Swaine, 1992; Miller and Kauffman,1998a). Mizrahi et al. (1997) and Ceccon et al. (2002, 2004) found in a 12-year-old TDF fragment that plants regenerated by sprouts were less common in the tree seedling community. However seedlings regenerated by seeds (more numerous) showed a significantly lower probability of survival. This result would explain the high percentage of adult trees originated by sprouts (Ceccon et al., 2004). Sprouting seems to be advantageous to many species including those that regenerate frequently by seeds, presumably because vegetative shoots may take advantage of the extensive root system and the substantial storage of metabolites in the remaining parts of the parent plant (Koop, 1987; Negrelle, 1995). The connection with a deeprooted tree makes TDF sprouts less vulnerable to shortage of water and nutrients in the soil upper layers.

\section{ABIOTIC FACTORS}

\section{The climatic seasonality}

TDF are formed by a large group of plant communities habiting warm climates (Aw), with a high climatic seasonality (Bullock, 1986; Murphy and Lugo, 1986), in which the beginning of the rain period can be predictable but the amount and periodicity of rains are very variable and unpredictable. In some TDF in Mexico, there may be years with eight consecutive months of drought (Bullock, 1986). This seasonal nature of rainfalls is correlated with the deciduous character of TDF and clearly plays a major role in structuring patterns of metabolic activity and growth in this biome.

In fact, the structure and ecophysiological characteristics of the TDF vegetation seem to be closely correlated with the duration and seasonal nature of the dry period (Lieberman, 1982; Reich and Borchert, 1984; Lieberman and Lieberman, 1984). In this context, the seasonal nature restricts the time period in which there are favorable conditions for the germination of seeds, survival, establishment and growth of the plants. Lieberman and $\mathrm{Li}$ (1992) found in a dry forest in Ghana that recruitment increases progressively during the rainier season, in which $40 \%$ of the annual germination was registered, as well as the lowest mortality rate $(4 \%)$. In a TDF in Mexico, more than $90 \%$ of the annual germination occurs in the three most humid months (Ramírez, 1996). In Guanacaste, Costa Rica, and in Yucatán, Mexico, an abrupt reduction of survival percentage during the dry season was detected (Gerhart, 1993; Ceccon et al., 2004). In this respect, water stress has been reported to be an important factor affecting seedling survival (Turner, 1990).

Another important aspect of the rainfall temporal variation in TDF is the variability in the annual volume of rains and the intensity and duration time of the dry and rainy periods. According to Ruthemberg (1980), these variations may be around $30 \%$, therefore the high level of water stress in the dry years is the cause of high mortality among seedling communities (Doley, 1981). Currently, there are few studies on this type of variability and its effects on the regeneration of these ecosystems.

\section{Soil fertility and moisture}

Half the dry forests in the world are in poor nutrient soils (Sánchez, 1976; Singh et al., 1989). Moreover, the low humidity restricts water and nutrient availability, since the supply of nutrients may vary depending on water availability, the quality of humus, and decomposition rates (Bradshaw, 1969).

Water soil availability is considered a key factor for the regeneration, survival and growth of seedling communities in TDF (Lieberman, 1982; Reich and Borchert 1984; Lieberman and Lieberman, 1984; Ceccon et al., 2004). However, many TDF species show the ability to adapt to low water soil availability, therefore the root/shoot ratio is much larger in the TDF plants than in those of rain forests. (Bullock, 1990).

In some TDF, consistent correlations among some composition and structure characteristics of seedlings and various soil properties were found (González and Zak, 1996; Johnston, 1992; Ceccon et al., 2002). Ceccon et al. (2002) found positive correlations between the number of individuals and the species richness of tree seedlings and the phosphorus content. Seedlings of different species differ only in their response to the availability of nutrients. In a TDF in Chamela, Mexico, it was found that fast growing-species required high 
availability of nutrients (Huante et al., 1995), light (Rincon and Huante, 1993) and phosphorus (Huante et al., 1995) and received little or no benefit from mycorrhizae fungi (Huante et al., 1993). These species also presented a forked root pattern (Huante et al., 1988) which was associated to the exploration and use of areas with high availability of resources (Fitter, 1985). In a TDF in Yucatán, Mexico, Ceccon et al.(2003) reported that seedling species richness and survival increased after fertilizer application $(\mathrm{N}$ and $\mathrm{P})$ in different stages of regeneration. These differences were determined to a great extent the level of success of the TDF species established and in agreement with findings by Vitouseck (1984) regarding tropical forests phosphorous deficiency.

\section{Natural disturbances and availability of resources}

Natural disturbances originate gaps in the canopy and a dynamic mosaic of succession phases interacting in time and space (Martinez-Ramos 1985). Depending on the size of the gap formed, the regeneration elements include from seed to sprouts and broken branches of surviving trees within and around the gap (Bazzaz, 1984).

Unlike tropical rain forests, there is no theory for gap dynamics in TDF and their role in species regeneration (Mooney et al., 1995), largely due to the structural characteristics of the vegetation, such as lower height, thickness and smaller size of trunks and branches, reduced stratification, high density of individuals, etc. (Murphy and Lugo, 1986; Terborgh, 1992, Swaine et al. 1990). Drastic changes in TDF may occur regarding the availability of resources generated by causes other than the formation of gaps, for example, their marked seasonal rainfall pattern (Bullock, 1986). Also, in the rain season, there might be a rainless period (nearly a month) which leads to the loss of leaves in some trees, and consequently to changes in the availability of light in the understorey vegetation (Huante and Rincón, 1998a, b). In TDF, the standing dead trees and dead branches with no leaves form small clearings when falling during common tropical storms in Central and North America. In these forests, scattered clearings of large sizes due to the fall of big cactus are formed (Huante and Rincón, 1998a). The first stage of seedling growth occur during the period of tree leaf production, when changes in the conditions of light are more drastic. The measurements of the radiation active through photosynthesis in the TDF of Chamela, Mexico suggested that the time required for the closure of the canopy as a result of production, from the beginning of the rain season, showed a large annual variation between 35 to 75 days (Barradas, 1991). Considering that germination occurs at the beginning of the rain season, it is then when most seedlings will experiment good conditions of light that will reduce gradually as the canopy closes. Yet, because of the low stratification and height of vegetation, there is plenty of light and the conditions of survival in the understorey vegetation do not diminish as much as in the tropical rain forests. These variations, however, will have different effects on species, since slowgrowth species and low response to changes of light will be less affected by the reduction of light than fast-growing species (Huante and Rincón, 1998a). The study of these great changes generated by seasonal nature may help us to understand what the TDF regeneration process is like when facing natural changes affecting the availability of resources.

Some authors have recently found signs of the effect of gaps on the regeneration and survival of some TDF species. Jha and Singh (1990) identified some patch distribution of species related to the dynamics of regeneration in a TDF in India. Oliveira-Filho et al. (1998) found in a TDF in Brazil five scrubs species that were exclusive to gaps and only two of them were occasionally detected outside the gaps. These authors also found species whose distribution was negatively correlated with the presence of gaps and were probably related to later successional stages, though they established in clearings as their seedlings were rarely found in the shade. It was concluded that most species required any quantity of light during the seedling phase and few species were specialists in shaded environments and, therefore, the amount of light filtering in the canopy could have strong effects in the regeneration of some species. In a TDF in Mexico, similar responses were found in the regeneration and survival of species in relation to the availability of light (Ceccon et al., 2003, 2004). Veenedaal et al. (1996) in a study carried out in Ghana, found that a low percentage of the species studied survived, during the dry season in the shade. In contrast, most of the individuals that survived were in the central part of the gaps. A quick reduction of the leaf water potential and of 
the stomatic conductivity indicated that seedlings growing in the shade experienced a water stress three to four weeks longer than the plants growing in gaps. The findings by various authors confirmed that drought could be a more important factor of stress for the vegetation in the shade than under the sun in dry forests (Givnish, 1988; Mulkey et al., 1991; Wright 1992; Kertiens, 1994; Grubb, 1995).

Ceccon et al. (2004) estimated a longer survival for seedlings of two secondary and fertilized TDF, with greater availability of light. Huante et al. (1998a) found in a TDF in Mexico that slowgrowing species were more favored when the light diminished than when it was stronger; on the other hand, the fast-growing species benefit more when they have access to more light, which suggests they are capable of remaining in the understory vegetation as seedlings and benefit from increases of light caused by disturbances (Rincón and Huante, 1993; Huante et al., 1998a).

\section{Anthropogenic disturbances and the use of fire}

In most ecosystems of the planet, human activity has induced various modifications of the natural regeneration processes. Fire, a commonly used tool in the management of agriculture in tropical areas, depending on its frequency and intensity, may substantially alter the natural succession process of an ecosystem (Quintana-Ascencio et al., 1996). In most TDF, fire is set by the traditional management technique of slash and burn and does not occur naturally.

Regeneration by seeds is strongly affected by fire. In a TDF in Chamela, Mexico, the density of viable seeds in the seed bank after the residue burning, reduced by $93 \%$, which showed the low adaptation to fire of the these species. Twenty three of the 30 species germinating from the seed bank before the fire were absent one day after it (Miller, 1999). According to a study carried out in a TDF in Yucatán, Mexico in the soils collected one year after the slash and burning of the forest in an area previously used for maize cultivation, the amount of germinated species was $32 \%$ more than in a 100-year-old forest. However, the increase in the number of species present after the burning of residues was due to the predominance of herbs associated with crops, accounting for $86 \%$ of the seed bank (Rico-Gray and Garcia -Franco, 1992). TDF were for long known for their great capacity of recovery after burnings, since many TDF species could regenerate by sprouts (Ewel, 1980).
The number of sprouts was reduced with the greater frequency and severity of fires, according to recent studies (Sampaio et al., 1993; Miller and Kauffman, 1998a,b). For example, in a TDF in Bolivia, disturbances like the removal of trees and low intensity fires increased regeneration by sprouts, but highly intense fires favored regeneration through seeds (Kennard, 2002). In a TDF in Brazil, 95\% of the individuals regenerated by sprouts after cutting, but only 10 to $43 \%$ sprouted after the residue burning (Sampaio et a.., 1993)

On the other hand, the disturbance can influence biotic interactions. As stated in prior studies, the anthropic disturbance negatively affects the sensitiveness of seedlings to the attack of herbivores (Hammond, 1995).

\section{CONCLUSIONS}

In TDF, the marked seasonal nature, high intraand interannual variability of rainfalls and the weak capacity of recolonization of many tree species, combined with the continuous expansion of agricultural and livestock activity can produce a landscape with permanent secondary vegetation, having a significant impact on the natural dynamics of TDF regeneration and their conservation.

The foregoing studies on TDF show that there are groups of species that respond to the increase of resources, mainly light and nutrients, but more conclusive studies are still required, mostly in the field to identify niches of regeneration for most species. On the other hand, there are some general classifications about water requirements, but the arguments used to account for the differences among species about the role of this resource are still scarce. It is necessary to develop further ecophysiological studies over the response of species to these essential resources for their growth, since they would be fundamental for a better understanding of the TDF successional dynamics. These studies would provide us with the tools needed for the design of successful strategies aimed to the restoration and conservation of these important and threatened forests. 


\section{RESUMO}

As florestas tropicais secas representam cerca da metade das florestas tropicais do mundo e são ecossistemas que estão sofrendo uma grande deterioração pelas atividades humanas. Neste artigo realizamos uma revisão de literatura sobre a dinâmica da regeneração das florestas tropicais secas enfocando principalmente nos fatores abióticos que influenciam esta regeneração, tais como, o clima estacional, a fertilidade e umidade do solo e as perturbações naturais e antrópicas. $\mathrm{O}$ principal objetivo é compreender um aspecto muito importante da dinâmica sucessional das florestas tropicais secas.

\section{REFERENCES}

Barradas, V. L. (1991), Radiation regime in a tropical dry deciduous forest in western Mexico. Theoretical Application Climatology, 44, 57-64.

Bazzaz, F. A. (1984), Dynamics of wet tropical forests and their species strategies. In: Medina,E.; Mooney, H. A. and Vazquez-Yanes, C. (Eds). Physiological Ecology of Plants of the Wet Tropics. La Haya, Holanda: Dr. Junk Publishers. pp. 37-49.

Borchert, R. (1984), Phenology and control of flowering in tropical trees, Biotropica, 15, 81-90.

Bradshaw, A. (1969), An ecologist viewpoint. In: Rorinson, I. (Ed.). Ecological Aspects of Mineral Nutrition of Plants. Oxford: Blackwell. pp 415-427.

Brokaw, N. V. L. (1982), Treefalls: frequency, timing and consequences. In: Leigh Jr., E.G.; Rand, A. S. and Windsor, D. M. (Eds). The Ecology of a Tropical Forest: Seasonal Rhythms and Long-term Changes. Washington, DC: Smithsonian Inst. Press. pp. 101-110.

Bullock, S. H. (1990), Abundance and allometrics of vines and self-supporting plants in a tropical deciduous forest in Mexico. Biotropica, 22, 22-35.

Bullock, S. H. and Solis-Magallanes J. A. (1990), Phenology of canopy trees of a tropical deciduous forest in Mexico. Biotropica, 22, 22-35.

Bullock, S. H. (1986), Climate of Chamela, Jalisco, and trends in the south coastal region of Mexico. Arch. Met Geophys Bioclimatol B, 36, 297-316.

Campbell, B. M.; Lynam, T. and Hatto, J. C. (1990), Small-scale in the recruitment of forest species during succession in tropical dry forest, Mozambique. Vegetatio, 87, 51-57.

Ceccon, E.; Omstead, I.; Vázquez-Yanes, C. and CampoAlves, J. (2002), Vegetation and soil properties in two tropical dry forests of differing regeneration status in Yucatán. Agrociencia, 36, 621-631.
Ceccon, E.; Huante, P. and Campo-Alves, J. (2003), Effects of nitrogen and phosphorus fertilization on the survival and recruitment of seedlings of dominant tree species in two abandoned tropical dry forests in Yucatán, Mexico. Journal of Forest Ecology and Management, 182, 387-402

Ceccon, E.; Sanchéz, S. and Campo-Alves, J. (2004), Tree seedling dynamics in two abandoned tropical dry forests of differing successional status in Yucatán, Mexico: a field experiment with $\mathrm{N}$ and $\mathrm{P}$ fertilization. Plant Ecology, 170 : (2), 12-26.

Daubenmire, R. (1972) Phenology and other characteristics of tropical semi-deciduous forest in north-western Costa Rica. Journal of Ecology, 60, 147-170.

Doley, D. (1981), Tropical and subtropical forests and woodlands. In: Kozlowisk, T. T. (ed.). Water deficits and plant growth. New York: Academic Press. pp 209-323.

Ewel, J. (1977), Differences between wet and dry sucesional tropical ecosystems. Geographic-EcologyTropical, 1, 103-117.

Ewel, J. (1980), Tropical succession: manifold routs to mature. Biotropica, 12, 2-7.

Ewel, J. (1986), Designing agricultural ecosystems for the humid tropics. Annual Review of Ecology and Systematics, 17, 245-271.

Fitter, A. H. (1985), Functional significance of root morphology and root system architecture.In: Fitter, A. H.; Atkinson, D.; Read, D. J. and Usher, M. B. (Eds). Ecological interactions in soil: Plants, microbes and animals. British Ecol. Soc. Spec. Publ. 4. Oxford, UK: Blackwell Sci. Publ. pp. 87-106.

Foster, R. (1982), The seasonal rhythm of fruitfall on Barro Colorado Island. In: Leigh Jr, E. G.; Rand, A. S. and Windsor, D. M. (Eds.). The ecology of a tropical forest. Washington, DC: Smithsonian Institution Press. pp. 151-172.

Garwood, N. (1982), Seasonal rhythm of seed germination in a semideciduous tropical forest. In: Leigh Jr, E. G.; Rand, A. S. and Windsor, D. M. (Eds.). The ecology of a tropical forest. Washington, DC: Smithsonian Institution Press. pp. 173-185.

Garwood, N. (1989), Tropical seed banks: a review. In: Leck,M. A.; Parker, V. T. and Simpson, R. L. (Eds.). Ecology of seed banks. Chapter 9. New York: Academic Press.

Gerhardt, K. (1998), Leaf defoliation of tropical dry forest tree seedlings-implications for survival and growth. Trees, 13, 88-95.

Gerhardt, K. and Hytteborn, H. (1992), Natural dynamics and regeneration methods in tropical dry forests- an introduction. Journal of Vegetation Science, 3, 361-364.

Givinsh, T. J. (1988), Adaptation to sun and shade whole plant perspective. Aust. J. Plant Physiol., 15, 63-92. 
Gonzalez, O. J. and Zak, D. R. (1996), Composition and structure of topical dry forest of St. Lucia,West Indies: the influence of edaphic properties and disturbance. Biotropica, 28, 618-626.

Grubb, P. J. (1995), Rain forest dynamics. The need for new paradigms. In: Shoy, S. C.; Edwards, D. S. and Booth, W. E. Tropical Rain Forest Research: Current Issues. Kluwer: The Hague.

Hammond, D. S. (1995), Post-dispersal seed and seedling mortality of tropical dry forest trees after shifting agriculture, Chiapas, Mexico. Journal of Tropical Ecology, 11, 295-313

Hopkins, M. S. and Grahan, A. W. (1983), Tree species composition of soil seed banks beneath lowland tropical rain forests in North Queensland, Australia. Biotropica, 15, 90-99.

Huante P.; Rincón E. and Gavito M. (1988), Root system analysis of seedlings of seven tree species from a tropical dry forest in Mexico. Trees: Structure and Function, 6, 77-82.

Huante, P.; Rincon E. and Allen E. B. (1993), Effect of vesicular arbuscular mycorrhizae on seedling growth of four tree species from the tropical deciduous forest in Mexico. Mycorrhiza, 2, 141-145.

Huante, P.; Rincón, E. and Chapin, III F. S. (1995), Responses to phosphorous of contrasting succession tree-seedling species from the tropical deciduous forest of Mexico. Functional Ecology, 9, 760-766.

Huante, P. and Rincón, E. (1998a), Responses to light changes in tropical deciduous woody seedlings with contrasting growth rates. Oecologia, 113, 53-66.

Huante, P.; Rincón, E. and Chapin III, F. S. (1998b), Foraging for nutrients, responses to changes in light, and competition in tropical deciduous tree seedlings. Oecologia, 117, 209-216

Janzen, D. H. (1988), Tropical dry forests: the most endangered major ecosystem. In: Wilson, E. O. (Ed.). Biodiversity. Washington, DC: National Academic Press. pp. 130-137.

Jha, C. S. and Singh, J. S. (1990), Compositions and dynamics of dry tropical forest in relation to soil texture. Journal of Vegetation Science, 1, 609-614

Johnston, M. H. (1992), Soil vegetation relationships in Tabonuco forest community in the Luquillo Mountains of Puerto Rico. Journal of Tropical Ecolology, 8, 253-263.

Kauffman, J. B. (1991), Survival by sprouting following fire in tropical forests of the eastern Amazon. Biotropica, 23, 210-224.

Kennard, D. (2002), Secondary forest succession in a tropical dry forest: patterns of development across a 50-year chronosequence in lowland Bolivia. Journal of Tropical Ecology, 18, 53-66.
Kertiens, G. (1994), Effects of low radiance intensity and high air humidity on morphology and permeability of plants cuticles, with special respect to plants cultures in vitro. In: Lumsde, P. J.; Nicholas, J. R. and Davies, W. J. (Eds.). Physiology, Growth and Development of Plants in Culture. Kluwer: The Hague. pp. 132-142.

Khurana, E. and Singh, J.S. (2001), Ecology of seed and seedling growth for conservation and restauration of tropical dry forest: a review. Coservation Biology, 28 : (1), 39-52.

Koo, H. (1987), Vegetative reproduction of trees in some European natural forests. Vegetatio, 72, 103-110.

Lieberman, D. (1982), Seasonallity and phenology in a dry tropical forest in Ghana. Journal of Ecology, 70, 791-806

Lieberman, D. and Li, M. (1992), Seedling recruitment patterns in tropical dry forest in Ghana. Journal of Vegetation. Science, 3, 375-382.

Lieberman, D. and Lieberman, M. (1984), The causes and consequences of synchronous flushing in a dry tropical forest. Biotropica, 16, 193-201.

Martinez-Ramos, M. (1985), Claros, ciclos vitales de los árboles tropicales y regeneracion natural de las selvas altas pernifolias. In: Gomez-Pompa, A. and Del Amo, S. (Eds.). Investigaciones sobre la regeneración de selvas en Veracruz, México. México: Alambra. v. 2. pp. 191-240.

Medina, E. and Cuevas, E. (1990), Propiedades fotosinteticas y eficiencia de uso de agua de plantas leñosas del bosque deciduo de Guanica: consideraciones generales yresultados preliminares. Acta cientifica (Puerto Rico), 4, 25-36.

Millar, P. M. (1999), Effects of deforestation on seed banks in a tropical deciduous forest of western Mexico. Journal of Tropical Ecology, 15,179-188

Miller, P. M. and Kauffman, J. B. (1998a) Seedling and sprout response to slash-and-burn agriculture in a tropical deciduous forest. Biotropica, 30, 538-546.

Miller, P. M. and Kauffman, J. B. (1998b), Effects of slash and burn agriculture on species abundance and composition of a tropical deciduous forest. Forest Ecology and Management, 103 : (2-3),191-201.

Mizrahi, A. P.; Ramos, J. M. P. and Jimenez-Osornio, J. J. (1997), Composition, structure and management potential of secondary dry tropical vegetation in two abandoned henequen plantations of Yucatan, Mexico. Forest Ecology and Management, 94, 79-88.

Mooney, H. A.; Bullock, S. H. and Medina, E. (1995), Introduction. In: Bullock, S. H.; Mooney, H. A. and Medina, E. (Eds.). Seasonally dry tropical forests. Cambridge: Cambridge University Press. pp. 1-8.

Mulkey, S. S.; Smith, A. P. and Wrigth, S. (1991), Comparative life history and physiology of two understory tropical herbs. Oecologia, 88, 163-173.

Murphy, P. G. and Lugo, A. E. (1986), Ecology of tropical dry forest. Annual Review. Ecology Systematic, 17, 67-88. 
Negrelle, R. (1995), Sprouting after uprooting of canopy trees in the Atlantic rain forest of Brazil. Biotropica, 27, 448-454.

Newberry, D. M. C.; Gartlan, J. S.; Key, J. M. and Waterman, P. G. (1986), The influence of drainage of soil phosphorus on the vegetation of Douala-edea Forest Reserve, Cameroon. Vegetatio, 65, 149-162.

Oliveira-Filho, A. T.; Curi, N.; Vilela, E. A. and Carvalho, D. A. (1998). Effects of canopy gaps, topography, and soils on the distribution of woody species in a Central Brazilian deciduous dry forest. Biotropica, 30, 362-375.

Quintana-Ascencio, P.; Gonzalez-Espinoza, M.; Ramirez-Marcial, N.; Dominguez-Vazquez, G. and Martinez-Icó, M. (1996), Soil seed banks and regeneration of tropical rain forest from milpa fields at the Selva Lacandona, Chiapas, Mexico. Biotropica, 28 : (2), 192-209.

Ramírez, R. C. B. (1996), Estructura y composición de las comunidades de plántulas del estrato arbóreo de selva baja caducifolia, en tres condiciones de disturbio en Acolapa, Morelos. Tesis de Licenciatura. Universidad Autonoma de Morelos, Cuernavaca, Morelos.

Ray, G. J. and Brown, B. J. (1994), Seed Ecology of woody species in a Caribbean dry forest. Restoration Ecology, 2 : (3), 156-163.

Reich, P. B. and Borchert, R. (1984), Water stress and tree phenology in tropical dry forest in the lowlands of Costa Rica. Journal of Ecology, 72, 61-64.

Rico-Gray, V. and García-Franco, J. (1992), Vegetation and soil seed bank on successional stages in tropical lowland deciduous forest. Journal of Vegetation Science, 3, 617-624.

Rincón, E. and Huante, P. (1993), Growth responses of tropical deciduous tree seedlings to contrasting light conditions. Trees: Strucure. and Function, 7, 202-207.

Rincón, E. and Huante, P. (1994), Influence of mineral nutrition availability on gorwth of tree seedlings from the tropical deciduous forest. Trees, 9, 93-97

Rincón. E.; Alvarez, A.; Gonzalez, G. D.; Huante, P. and Hernandez, A. (1999), Restauración de selvas bajas caducifolias. Gaceta Ecológica, 53, 62-71.

Ruthemberg, H. (1980), Farming systems in the tropics. New York: Oxford University Press. 424 pp.

Sabogal, C. (1992), Regeneration of tropical dry forests in central America, with examples from Nicaragua. Journal of Vegetation Science, 3, 407-416.

Sampaio, E. V. S. B.; Salcedo, L. H. and Kaufman, J. B. (1993), Effect of different fire severities on coppicing of caatinga vegetation in Serra Talhada, PE, Brasil. Biotropica, 25, 452-460.

Sanchez, P. A. (1976), Properties and Management of Soils in the Tropics. New York: John Wiley and Sons.
Singh, J. S.; Raghubashi, A. S.; Singh, R. S. and Srivastava, S. C. (1989), Microbial biomass acts as a source of plant nutrients in dry tropical forest and savanna. Nature, 338, 499-500.

Skoglund, J. (1992), The role of seed banks in vegetation dynamics and restoration of dry tropical systems. Journal of Vegetatio Science, 3, 357-360.

Swaine, M. D. (1992), Characteristics of dry forests in West Africa and the influence of fire. Journal of Vegetatio Science, 3, 365-374.

Swaine, M. D. (1996), Rainfall and soil fertility limiting forest species distribution in Ghana. Journal of Ecology, 84, 419-428.

Swaine, M. D.; Lieberman, D. and Hall, J. B. (1990), Structure and dynamics of a tropical dry forest in Ghana. Vegetatio, 88, 31-51.

Terborgh, J. (1992), Diversity and the tropical rain forest. New York: Scientific American Library.

Turner, I. M. (1990), The seedling survivorship and growth of three Shorea species in a Malaysian tropical rain forest. Journal of Tropical Ecology, 6, 469-478.

Uhl, C. and Clarck, K. (1983). Seed ecology on selected Amazon basin sucesional species. Botanical Gazette, 144, 419-423.

Veenendaal, E. M.; Swaine, M. D.; Agyeman, V. K.; Blay, P.; Abebrese, I. K. and Mullins, C. E. (1996), Differences in plant and soil water relations in and around a forest gap in West Africa during the dry season may influence seedling establishment and survival . Journal of Ecology, 84 : (1), 83-90.

Vitousek, P. (1984), Litterfall, nutrient cycling and nutrient limitation in tropical forests. Ecology, 65, 285-298

Wright, S. J. (1992), Seasonal drought, soil fertility and the species density of tropical forest plant communities. Trends in Ecology and Evolution, 7, 260-263.

Received: September 09, 2004; Revised: October 29, 2004; Accepted: August 11, 2005. 